\title{
Les musées de plein air allemands : un instrument d'analyse du milieu technique préindustriel
}

\section{Michel Noël}

\section{(2) OpenEdition \\ 12 Journals}

Édition électronique

URL : https://journals.openedition.org/tc/754

DOI : $10.4000 /$ tc. 754

ISSN : 1952-420X

Éditeur

Éditions de l'EHESS

\section{Édition imprimée}

Date de publication : 1 septembre 1991

ISSN : 0248-6016

\section{Référence électronique}

Michel Noël, « Les musées de plein air allemands : un instrument d'analyse du milieu technique préindustriel », Techniques \& Culture [En ligne], 15 | 1991, mis en ligne le 12 janvier 2006, consulté le 29 septembre 2022. URL : http://journals.openedition.org/tc/754 ; DOI : https://doi.org/10.4000/tc.754

Ce document a été généré automatiquement le 29 septembre 2022.

Tous droits réservés 
Les musées de plein air allemands : un instrument d'analyse du milieu technique préindustriel

Michel Noël 